\title{
Teriparatidin ilaçlarla ilişkili çene osteonekrozu tedavisindeki etkinliği: Hayvan çalışması
}

\author{
Cihan Topan(0000-0003-0978-8052) ${ }^{\alpha}$, Erdem Kılliç(0000-0002-7266-3749) $)^{\beta}$, Eser KIlıç(0000-0002-0459-8228) ${ }^{\gamma}$, \\ Saim Özdamar(0000-0003-4440-5360 ${ }^{\lambda}$, Emin Kaymak(0000-0002-3818-2693) ${ }^{\mu}$
}

Selcuk Dent J, 2020; 7: 155-162 (Doi: 10.15311/selcukdentj.377192)

Basvuru Tarihi: 10 Ocak 2018 Yayına Kabul Tarihi: 02 Nisan 2019

öz

Teriparatidin ilaçlarla ilişkili çene osteonekrozu tedavisindeki etkinliği: Hayvan çalışması

Amaç: Teriparatid (TP) kemik oluşumunu uyaran osteoanabolik bir ilaçtır. Çalışmanın amacı, bifosfonat (BP) uygulamasını takiben diş çekimi sonrasında çene kemiklerinde oluşan osteonekrozun tedavisinde teriparatidin etkinliğinin deneysel olarak araştııımasıdır.

Gereç ve Yöntemler: 48 adet rat rastgele dört gruba ayrıldı: IKontrol grubu; II-BP grubu, III-TP grubu, IV-Antibiyotik grubu. İki, üç ve dördüncü gruba sekiz hafta boyunca zoledronik asit uygulandı. İșlemden bir hafta sonra tüm hayvanların alt çene sol azı dişleri çekildi ve çekim soketlerinde kemik defekti oluşturuldu. Böylece iki, üç ve dördüncü gruptaki ratların alt çene sol posterior bölgelerinde osteonekroz oluşturuldu. Ardından, osteonekrozun tedavisi için üçüncü gruptaki ratlara iki ay boyunca TP, dördüncü gruptaki ratlara iki hafta boyunca antibiyotik verildi ve hayvanlar sakrifiye edildi.

Bulgular: Biyokimyasal incelemede, tüm grupların ortalama BALP ve CTX değerleri arasında istatistiksel olarak anlamlı bir fark bulunmamıștır $(p>0.05)$. Radyolojik incelemede, kontrol grubunun ortalama defekt hacmi BP grubununkinden anlamlı olarak yüksek bulunmuștur $(p<0.05)$. TP grubunun ortalama defekt hacmi antibiyotik ve BP grubununkinden düşük çıksa da bu fark istatistiksel olarak anlamlı bulunmamıştır $(p>0.05)$. Histolojik incelemede, BP grubunda nekrotik kemik dokusu görülmüştür. TP grubunda genel olarak herhangi bir nekrotik yapı izlenmemiştir. TP grubundaki osifikasyonun BP ve antibiyotik grubundan daha iyi olduğu gözlenmiştir. Klinik incelemede BP, antibiyotik ve TP grubunda sırasıyla $\% 45, \% 60$ ve $\% 9,1$ oranında nekrotik kemik varlığı tespit edilmiştir.

Sonuç: TP tedavisinin osteonekrozun tedavisinde kısmen olumlu etkileri olduğu görülmüştür. Bu tedavinin ideal doz ve süresinin belirlenmesi için ileri deneysel ve klinik çalışmalara intiyaç vardır.

\section{ANAHTAR KELIMELER}

Bifosfonat, osteonekroz, teriparatid

Bifosfonatlar (BP), kemik metabolizması bozukluklarıyla ilgili hastalıkların tedavisinde kullanılan ilaç grubudur. Bu ilaçların kullanımına bağı meydana gelen ciddi yan etkilerden biri de BP'ye bağlı çene osteonekrozudur

\section{ABSTRACT}

Teriparatide's potential role in the treatment of medicationrelated osteonecrosis of the jaw: An animal study

Background: Teriparatide (TP) is an osteoanabolic drug that stimulates bone formation The aim of the study is to investigate the efficacy of teriparatide in the treatment of osteonecrosis of the jaw bones after tooth extraction following bisphosphonate (BP) administration.

Materials and Methods: Rats were divided randomly into four groups: I-Control group; II-BP group, III-TP group, IV-Antibiotic group. Zoledronic acid was injected to the second, third and fourth group for eight weeks. A week after injections, mandibular left molars extraction was performed and bone defect were created in the same regions of all animals. In this way, osteonecrosis was created in the posterior regions of the mandible in the second, third and fourth group. For the treatment of osteonecrosis, TP was injected to rats in the third group; antibiotic was injected to rats in the fourth group and animals were sacrificed.

Results: There was no statistically significant difference between the mean BALP and CTX values of all groups biochemically $(p>0.05)$. In radiological examination, the mean defect volume of the control group was significantly higher than that of the BP group $(p<0.05)$. Although mean defect volume of TP group was lower than that of antibiotic and BP group, this difference was not statistically significant $(p>0.05)$. Histologically, necrotic bone tissue formation was observed in the BP group. No necrotic tissue was observed in the TP group. Ossification was better in TP group compared to BP and antibiotic group. In clinical evaluation, the rate of necrotic bone formation in BP, antibiotic and TP groups were $45 \%, 60 \%$ and $9.1 \%$, respectively.

Conclusions: TP therapy has partially positive effects in the treatment of osteonecrosis. Further experimental and clinical studies are required for the determination optimum dose and duration of this treatment modality.

\section{KEYWORDS}

Bisphosphonate, osteonecrosis, teriparatide

(BRONJ). ${ }^{1}$ Amerikan Oral ve Maxillofasiyal Cerrahi Birliği'nin (AAOMS) 2014 yilında yayınladığı son bildiride, maksilla ve mandibulada oluşan çene osteonekrozlarının sadece BP'lere bağlı olmadığı,

\footnotetext{
${ }^{\alpha}$ Erciyes Üniversitesi Diş Hekimliği Fakültesi Ağız, Diş ve Çene Cerrahisi Bölümü, Kayseri, Türkiye

${ }^{\beta}$ Bezmialem Vakıf Üniversitesi Diş Hekimliği Fakültesi Ağız, Diş ve Çene Cerrahisi Anabilim Dalı, İstanbul, Türkiye

${ }^{\gamma}$ Erciyes Üniversitesi Tıp Fakültesi Biyokimya Anabilim Dalı, Kayseri, Türkiye

$\lambda$ Pamukkale Üniversitesi Tıp Fakültesi, Histoloji ve Embriyoloji Anabilim Dalı, Denizli, Türkiye

${ }^{\mu}$ Yozgat Bozok Üniversitesi Tıp Fakültesi, Histoloji ve Embriyoloji Anabilim Dalı, Yozgat, Türkiye
} 
diğer antirezorptif ve antianjiojenik ilaçların kullanımına bağlı da meydana gelebildiği yer almıştır. Bu yüzden BRONJ tanımının; çenelerin ilaçla ilişkili osteonekrozu (MRONJ) olarak değiştirilmesi önerilmiştir. ${ }^{2}$ Son zamanlarda, MRONJ tedavisi için çeşitli yöntemler denenmiştir ancak tam olarak güvenli ve etkili bir tedavi protokolü henüz geliştirilememiştir. ${ }^{3}$

Sentetik bir polipeptid hormonu olan teriparatid (rekombinant insan paratiroid hormon 1-34), kemik oluşumunu uyaran ve osteoporoz tedavisinde kullanılan osteoanabolik bir ilaçtır. ${ }^{4}$ Teriparatidin (TP) periyodik olarak uygulanmasıyla kemik mineral yoğunluğu ve kemiğin biyomekanik dayanıklılı̆ı artar. $^{5,6}$ Literatürde TP'nin düşük dozda aralıklı olarak kullanılmasının MRONJ'un tedavisinde etkili olduğu ilk defa 2007 yılında Harper ve Fung tarafından rapor edilmiştir. ${ }^{7}$ Birkaç vaka raporunda TP uygulamasının MRONJ tedavisinde yararlı olduğu gösterilse de ilacın etki mekanizması tam olarak çözülememiştir. ${ }^{8}$ Ayrıca MRONJ tedavisinde TP'nin ideal uygulama süresi ve dozu hakkında net bir bilgi yoktur. ${ }^{3}$ Bu çalışmada, TP uygulamasının MRONJ tedavisindeki etkinliğini değerlendirmeyi amaçladık.

\section{GEREÇ VE YÖNTEM}

\section{İlaç uygulamaları ve diş çekimi}

Bu çalışma, Erciyes Üniversitesi Hayvan Deneyleri Etik Kurulu tarafından onaylandı (Protokol no:143, Kayseri, Türkiye). 48 adet Wistar Albino cinsi dişi rat rastgele dört gruba ayrıldı. İlk gruptaki (Kontrol grubu) hayvanlara hiçbir ilaç uygulanmadı. İkinci (BP grubu), üçüncü (TP grubu) ve dördüncü (Antibiyotik grubu) gruptaki hayvanlara $0,1 \mathrm{mg} / \mathrm{kg}$ zoledronik asit (Zometa, Novartis Pharma AG, Basel, İsviçre) haftada üç kez Barba-Recreo ve arkadaşlarının çalışmasında tarif edildiği gibi sekiz hafta boyunca intraperitoneal olarak enjekte edildi. ${ }^{9}$ BP tedavisi sonrası tüm hayvanların genel anestezi (Ketamin Hidroklorür 50 mg / kg + Xylazin Hidroklorür 8 mg / kg) altında mandibular sol birinci ve ikinci molar dişleri çekildi. Çekim soketlerine Biasotto ve arkadaşlarının yaptığı bir çalışmada tarif edildiği şekilde kemik defekti oluşturuldu. ${ }^{10}$ Diş çekimi sonrası her denekte standart olması açısından diş çekim soketinde küçük rond frezin çapı kadar (1.4 mm) defekt oluşturuldu. Cerrahi işlem sonrası sekiz hafta boyunca osteonekroz gelişmesi için beklenildi. Bu sürenin sonunda TP grubundaki ratlara, iki ay boyunca her gün $30 \mu \mathrm{g} / \mathrm{kg}$ paratiroid hormon analoğu (Forsteo ${ }^{\circledR}$ Teriparatid $250 \mathrm{mcg} / \mathrm{ml}, 3 \mathrm{ml}$ enjeksiyon kalemi, Lilly, Türkiye) subkütan olarak enjekte edildi. Antibiyotik grubundaki ratlara ise her gün $50 \mathrm{mg} / \mathrm{kg}$ penisilin (Duocid $1 \mathrm{~g}$ im / iv, 1 Flakon, Pfizer) intraperitoneal olarak uygulandı. Bu sürenin sonunda, tüm hayvanlar radyolojik, histolojik, klinik değerlendirmeler için sakrifiye edildi.

\section{Klinik değerlendirme}

Ratlar sakrifiye edildikten sonra örnekler abse ve açığa çıkmış nekroze kemik varlığının değerlendirilmesi için çıplak gözle muayene edildi. Çekim soketlerindeki iyileşmenin klinik olarak değerlendirilmesi için mukozal kapanma varlığı incelendi. Değerlendirme sonuçlarına göre (0) bozuk iyileşme (abse varlığı, açığa çıkmış nekroze kemik), (1) kısmi kapanma mevcut, (2) mukozal kapanma tamamlanmış, sorunsuz iyileşme olarak skorlandı.

\section{Radyolojik değerlendirme}

Bilgisayarlı tomografi (BT) çekimleri Newtom-BT cihazı (QR Verona, Verona, İtalya) vasıtasıyla $110 \mathrm{kV}$ güç, $0.55 \mathrm{~mA}$ akımla her bir örnekten $0.15 \mathrm{~mm}$ kesit kalınlığında görüntüler alınarak gerçekleştirildi. Kesitlerden alınan DICOM (Digital Imaging and Communications in Medicine) uyumlu radyolojik görüntüler Planmeca Romexis 3.8.3.R 15 bit (Romexis, Finlandiya) programı kullanılarak; sagittal, transversal ve vertikal yönlerde değerlendirmeye alındı. Diş çekimi sonrası iyileşme ve rezorpsiyona bağlı meydana gelen kemiksel değişikliklerin değerlendirilmesi için radyolojik kesitlerde görülen rezorpsiyon miktarı ve defektin hacmi hesaplandı. Diş çekimi sonrası alveol kemiğinde oluşan rezorpsiyonun hacmini hesaplamak için her bir deney hayvanının sagital yöndeki görüntüsünde, defektin başladığı noktadan bittiği noktaya kadar radyolusent alanın sınırları işaretlendi ve total defekt hacmi milimetreküp cinsinden üç boyutlu olarak ölçüldü. Bu ölçümler ile diş çekimi sonrası alveol kemikteki iyileşme miktarlarının gruplar arası kıyaslaması yapıldı.

\section{Biyokimyasal değerlendirme}

Deney hayvanlarından sakrifikasyon öncesi kardiak yolla ortalama 5 cc kan alındı. Kan örnekleri antikoagülan içermeyen tüplere alınarak 3000 x g'de 10 dakika santrifüj edilerek serum kısımları ayrıldı. Elde edilen serumlar eppendorf tüplerine paylaştırıldı ve biyokimyasal ölçümlerin yapılacağı güne kadar $80^{\circ} \mathrm{C}$ 'de muhafaza edildi. Çalışma günü tüm serum örnekleri oda sıcaklığında çözdürüldü. Serum Tip 1 Kollagen Terminal Çapraz Bağlı Telopeptid (CTX-1) ve kemiğe özgü alkalin fosfataz (BALP) seviyeleri, üreticinin talimatlarına uygun şekilde ratlara özel ELISA kitleri (Sunred Biological Technology CO., Ltd, Shanghai, China) kullanılarak analiz edildi.

\section{Histolojik değerlendirme}

Deney hayvanlarının alt çenesi 3'er cm'lik parçalar halinde küçültüldü ve \%4'lük nötral tamponlanmış formalin içinde 24 saatlik fiske edildi. Blok halinde gelen kemik dokusundan 2-3 mm kalınlığında kesitler alındı ve örnekler etanol içeren alkol havuzlarında dehitrate edildi. Dehitrate edilen örnekler alkolTecnovit karışımında 7200 içerisinde 24 saat vakum altında infiltre edildi. Daha sonra, örnekler metil 
metakrilat (Tecnovit 7200) içeren plastik kalıplara gömüldü ve kutucuklar $40^{\circ} \mathrm{C}$ 'de, dalga boyu $450 \mathrm{~nm}$ olan ışık altında sekiz saat süre ile polimerize edildi. Örnekler lam üzerine yapıştırıldıktan sonra hassas kesme cihazı (Exakt 300 CL, Exakt Apparatbau, Norderstad, Almanya) ve zımparalar yardımıyla $40 \mu \mathrm{m}$ kalınlığına kadar inceltildi. Histolojik kesitler hemotoksilen ve eozin boyama yöntemi ile boyandıktan sonra, metil metakrilat kullanılarak üzerleri lamel ile kapatıldı. Tüm kesitler ışık mikroskobu altında epitel doku şekillenmesi, kemik oluşumu açısından değerlendirildi.

\section{İstatistiksel analiz}

Tüm istatistiksel değerlendirmelerde SPSS 22.0 (SPSS Inc., Chicago, IL, ABD) istatistik yazılımından faydalanıldı. Verilerin normal dağılımı 'Shapiro-Wilk' testi ile değerlendirildi. Normal dağılım göstermeyen değişkenlerde Kruskal-Wallis testi uygulandı. Kategorik değişkenlerde Ki-Kare analizi yapıldı. $p<0,05$ düzeyi istatistiksel olarak anlamlı kabul edildi.

\section{BULGULAR}

\section{Klinik bulgular}

Hayvanların dördü deney sırasında öldü ve çalışmadan çıkartıldı (BP ve TP grubundan birer, antibiyotik grubundan iki rat öldü). Kontrol grubundaki hayvanların \% 83'ünde fizyolojik iyileşme görüldü. BP grubundaki hayvanların sadece \%18'inde tamamen iyileşme görüldü (Resim 1). Ayrıca, BP grubundan üç, antibiyotik grubundan iki hayvanın diş çekim bölgesinde abse oluşu gözlendi. TP grubundaki deneklerin \%72'sinde çekim bölgesinin mukoza ile kısmen kapandığı tespit edildi. BP, antibiyotik ve TP grubunda sırasıyla \%45, \%60 ve \%9,1 oranında nekrotik kemik varlığı tespit edildi (Tablo 1) (Resim 2).

Tablo 1.

Kontrol ve deney gruplarının örneklerinin diş çekim bölgelerinin klinik olarak değerlendirilmesi

\begin{tabular}{|lccc|}
\hline & \multicolumn{3}{c}{ Mukozal Kapanma (n,\%) } \\
\hline G (Ekpoze & $\begin{array}{c}1 \text { (Kısmi } \\
\text { nekroze } \\
\text { kemik) }\end{array}$ & $\begin{array}{c}2 \text { (Tam } \\
\text { iyileşme) }\end{array}$ & iyileşme) \\
\hline Kontrol $(n=12)$ & 0 & $2,(16,7)$ & $10,(83,3)$ \\
\hline BP $(n=11)$ & $5,(45,5)$ & $4,(36,4)$ & $2,(18,2)$ \\
\hline TP $(n=11)$ & $1,(9,1)$ & $8,(72,7)$ & $2,(18,2)$ \\
\hline Antibiyotik $(n=10)$ & $6,(60)$ & $3,(30)$ & $1,(10)$ \\
\hline
\end{tabular}

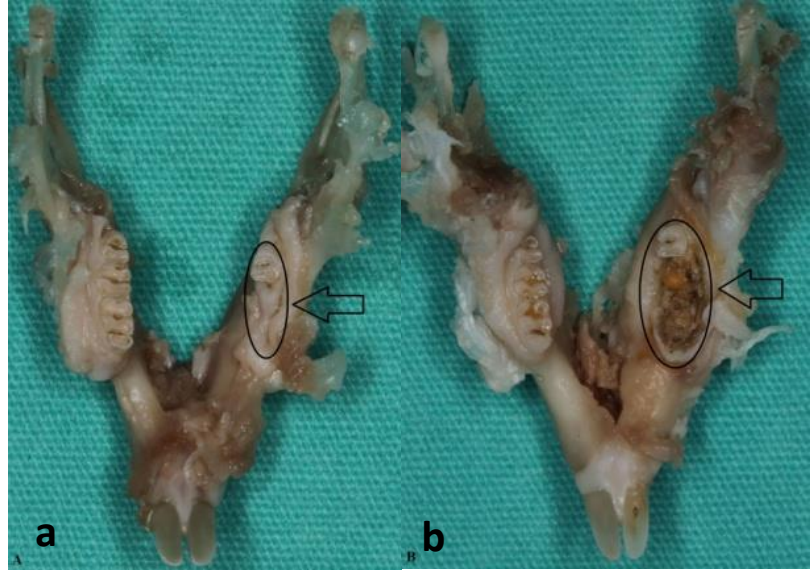

Resim 1.

a) Kontrol grubuna ait örnekte dis cekim bölgesinin tamamen mukoza ile kapandığı görülmektedir (Siyah ok), b) BP grubuna ait örneğin alt çenesinde açıktaki osteonekrotik kemik bölgesinin görüntüsü izlenmektedir (Siyah ok)

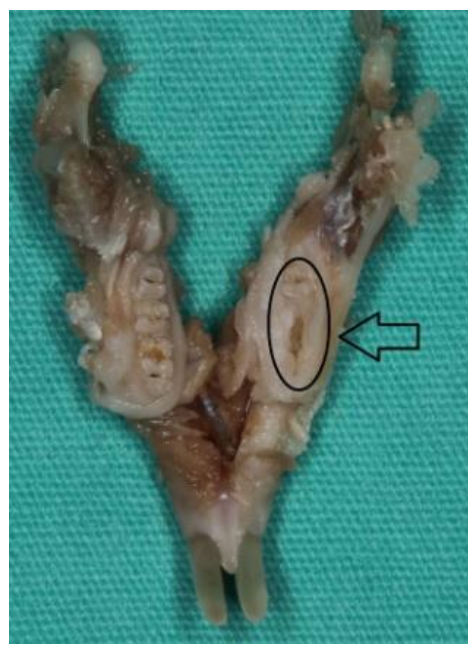

Resim 2.

TP grubuna ait örnekten elde edilen alt molar diş bölgesindeki çekim boşluğunun mukoza ile kısmen

kapandığı görülmektedir (Siyah ok)

\section{Biyokimyasal bulgular}

TP grubunun ortalama BALP değeri, kontrol grubu dışındaki diğer gruplara göre daha yüksek olarak bulundu. Tüm grupların ortalama BALP değerleri arasında istatistiksel olarak anlamlı bir fark bulunmadı ( $p>0.05$ ) (Tablo 2).

Tablo 2.

Kontrol ve deney grupları BALP değeri açısından biyokimyasal inceleme sonuçları

\begin{tabular}{|c|c|c|}
\hline Gruplar & BALP Ortalama $\pm S S$ & $\mathbf{P}$ \\
\hline Kontrol $(n=12)$ & $11,60 \pm 3,52$ & \multirow{4}{*}{0,181} \\
\hline $\operatorname{BP}(n=11)$ & $8,21 \pm 3,60$ & \\
\hline $\operatorname{TP}(n=11)$ & $10,25 \pm 3,43$ & \\
\hline Antibiyotik $(n=10)$ & $9,90 \pm 3,90$ & \\
\hline
\end{tabular}

Veriler, ortalama \pm S.S. olarak ifade edildi. 
TP grubunun ortalama CTX-1 değeri diğer gruplara kıyasla yüksek çıksa da tüm grupların ortalama CTX-1 değerleri arasında istatistiksel olarak anlamlı fark bulunmadı ( $p>0.05$ ) (Tablo 3$)$.

Tablo 3.

Kontrol ve deney grupları CTX-1 değeri açısından biyokimyasal inceleme sonuçları

\begin{tabular}{|c|c|c|}
\hline Gruplar & CTX-1 Ortalama $\pm S S$ & $\mathbf{P}$ \\
\hline Kontrol $(n=12)$ & $5,97 \pm 3,70$ & \multirow{4}{*}{0,551} \\
\hline $\mathrm{BP}(n=11)$ & $6,36 \pm 2,03$ & \\
\hline $\operatorname{TP}(n=11)$ & $7,76 \pm 3,53$ & \\
\hline Antibiyotik $(n=10)$ & $6,61 \pm 2,58$ & \\
\hline
\end{tabular}

Veriler, ortalama \pm S.S. olarak ifade edildi.

\section{Radyolojik bulgular}

Radyolojik incelemeler sonrası defekt hacmi değeri ortalaması kontrol grubunda en düşük, BP grubunda ise en yüksek olarak ölçülmüştür. Bu iki grup arasındaki farklılık istatistiksel olarak anlamlı olarak bulunmuştur $(p<0.05)$. TP grubunun ortalama defekt hacmi değeri antibiyotik grubunkinden düşük çıksa da bu fark istatistiksel olarak anlamlı bulunmamıştır ( $p>0.05)$ (Tablo 4).

Tablo 4.

Kontrol ve deney gruplarının defekt hacmi değeri açısından radyolojik inceleme sonuçları

\begin{tabular}{|c|c|c|}
\hline Gruplar & Defekt Hacmi Ortalama \pm SS & $\mathbf{P}$ \\
\hline Kontrol $(n=12)$ & $5,08 \pm 2,15^{a}$ & \multirow{4}{*}{0,04} \\
\hline $\mathrm{BP}(\mathrm{n}=12)$ & $9,00 \pm 5,59^{\mathrm{b}}$ & \\
\hline $\operatorname{TP}(n=12)$ & $6,82 \pm 1,33^{a, b}$ & \\
\hline Antibiyotik ( $n=12)$ & $7,90 \pm 2,73^{\text {a.b }}$ & \\
\hline
\end{tabular}

Veriler, ortalama \pm S.S. olarak ifade edildi. a,b aynı sütundaki farklı harfler istatistiksel olarak birbirinden anlamlı derecede farklığı ifade etmektedir.

\section{Histolojik Bulgular}

Kontrol grubundaki histolojik kesitlerde keratinize çok katlı yassı epitelin şekillenmiş ve kemik dokusunun iyileşmiş olduğu gözlenmiştir. Herhangi bir inflamasyon bulgusuna rastlanmamıştır. Diş çekim kavitesinde yeni kemik oluşumu görülmüştür (Resim 3). BP grubunda yara bölgesindeki epitel dokusunun tam yenilenmediği gözlenmiştir. Nekroza bağlı olarak hasar gören kemik dokusunun tamamen iyileşmediği, yer yer boşlukların olduğu görülmüştür. Diş çekim soketinin bağ dokusu ile dolmuş olduğu ve kemik dokusu oluşumunun eksik kaldığı gözlenmiştir (Resim 4). TP grubundaki histolojik kesitlerde epitel dokusunun şekillenmiş olduğu gözlenmiş ve herhangi bir nekrotik yapı izlenmemiştir. Bazı kesitlerde kemik dokusu yapımı aktivitesinin artmış olduğu görülmüştür. Kemik oluşumunun BP gruba kıyasla daha fazla ve kemik dokusu aralarındaki boşlukların daha iyi doldurulmuş olduğu gözlenmiştir. Bu grupta kemik dokusunun parçalı da olsa oluştuğu ama kontrol grubuna kıyasla dokular arası bütünlüğün düzensiz olduğu görülmüştür (Resim 5). Antibiyotik grubunda ise yara bölgesinde epitel dokusunun tam şekillenmediği gözlenmiştir. Kemikleşmenin trabeküler tarzda olduğu, kemik trabeküllerinin şekillendiği ama aralarda büyük boşlukların var olduğu görülmüştür. Diş çekim boşluklarının bağ dokusu ile dolduğu ve kemik dokusundaki iyileşmenin kontrol ve TP grubuna göre daha kötü olduğu gözlenmiştir (Resim 6).

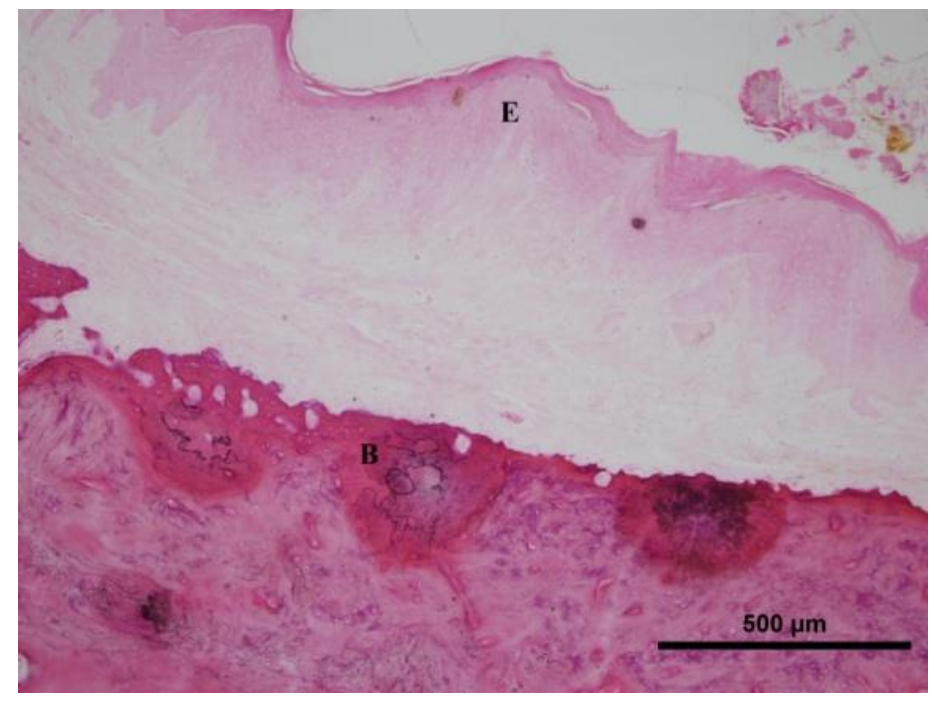

Resim 3.

Kontrol grubuna ait histolojik kesitlerlerde keratinize çok katlı yassı epitelin (E) şekillenmiş olduğu ve diş çekim boşluğunun kemik dokusu (B) ile dolduğu görülmektedir (Hematoksilen-Eozin, Objektif büyütme X 20)

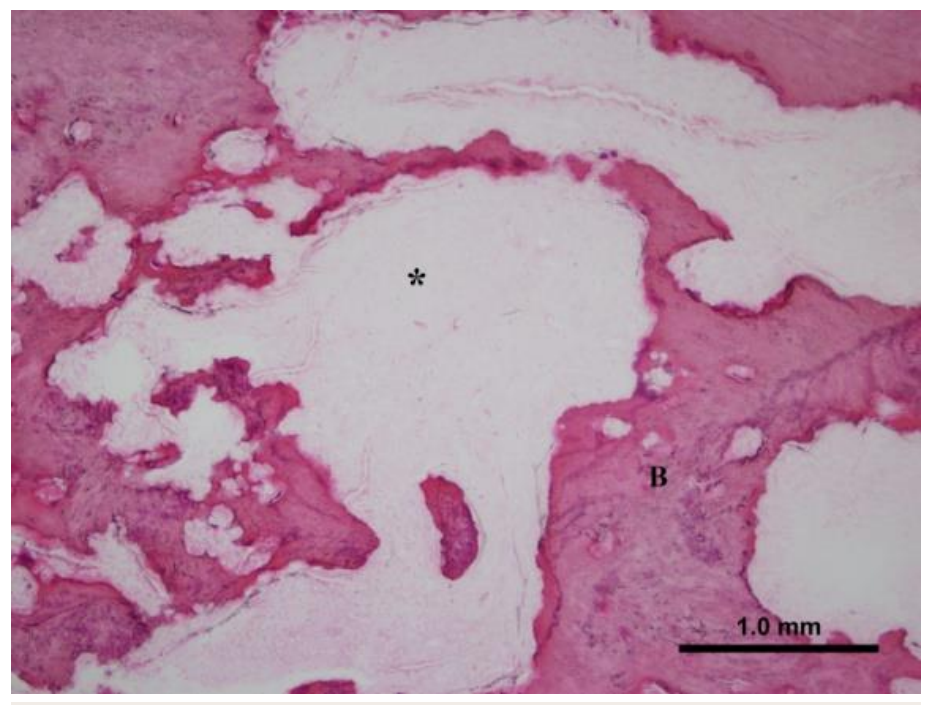

Resim 4.

BP grubunun histolojik kesitlerinde nekroza bağlı olarak hasar gören kemik dokusunun (B) tam iyileșmediği, yer yer boşlukların $(*)$ olduğu ve bu boşlukların yeni kemik dokusu ile tam kapanmadığı görülmektedir (Hematoksilen-Eozin, Objektif büyütme X 10) 


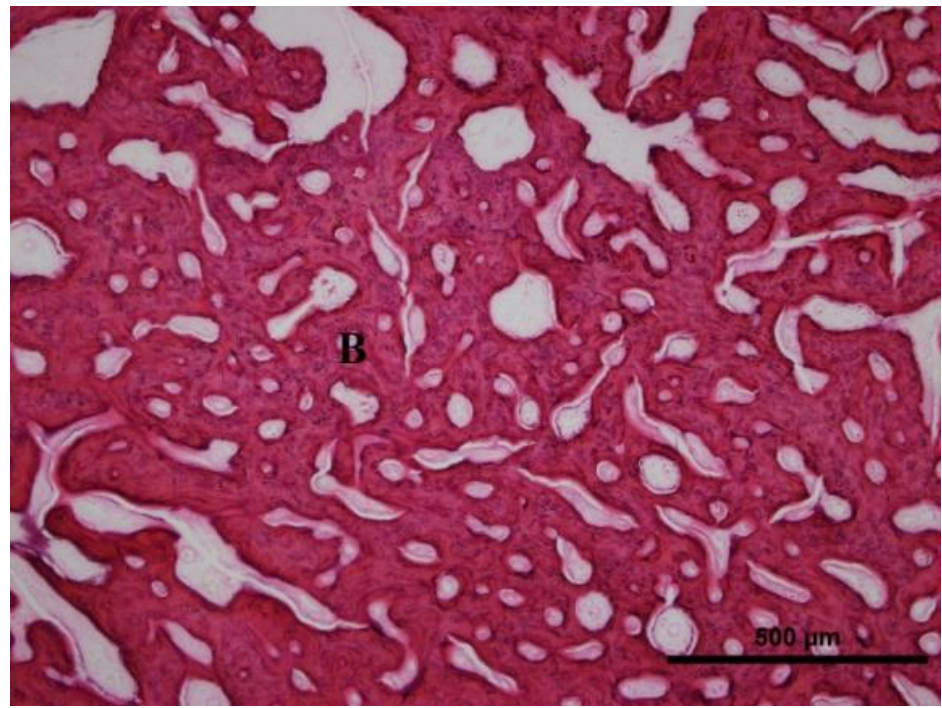

Resim 5.

TP grubuna ait histolojik kesitlerinde kemikleşmenin BP grubuna kıyasla daha fazla olduğu ve kemik dokusu (B) aralarındaki boşlukların daha iyi doldurulmuş olduğu gözlenmektedir (Hematoksilen-Eozin, Objektif büyütme X 10)

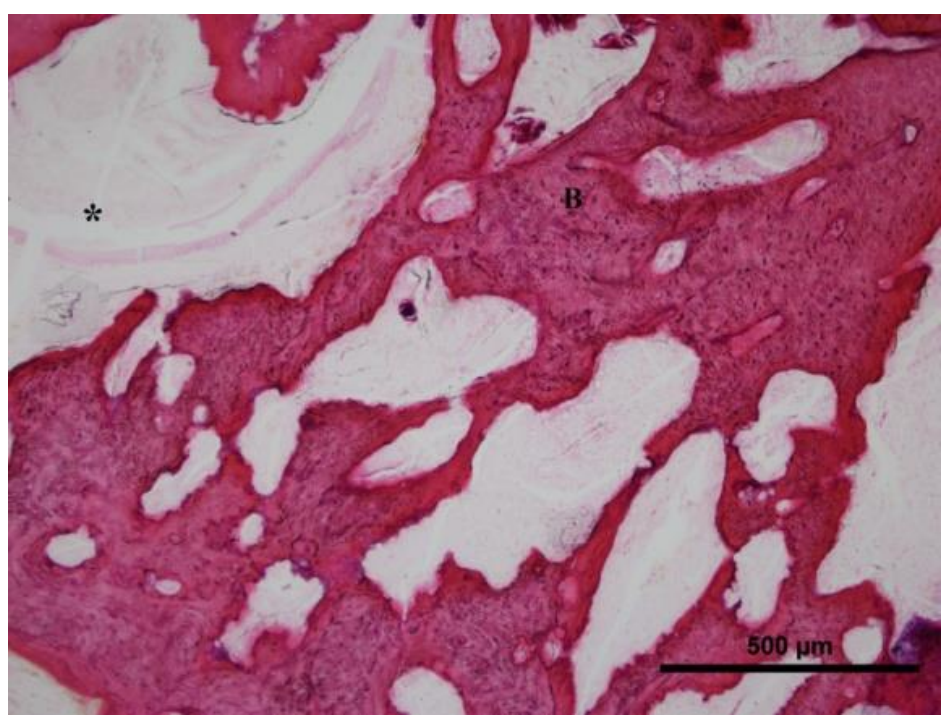

Resim 6.

Antibiyotik grubuna ait histolojik kesitlerde kemikleşmenin trabeküler tarzda olduğu, kemik trabeküllerinin (B) şekillendiği fakat aralarda büyük boşlukların (*) var olduğu görülmektedir (Hematoksilen-Eozin, Objektif büyütme X 10)

\section{TARTIŞMA}

MRONJ gelişiminde anjiyogenezin engellenmesi, bağışıklığın baskılanması, yumuşak doku toksisitesi, inflamasyon veya enfeksiyon, genetik yatkınlık önemli faktörler olarak görülse de hastalığın patogenezindeki en önemli faktör kemik yapım yıkım döngüsünün değişmesidir. BP ve diğer antirezorptif ilaçlar, osteoklastların farklılaşmasını ve işlevini baskılarlar. Bunun sonucunda kemik rezorpsiyonu ve yeniden şekillenmesi azalır, apoptozis artar. ${ }^{2}$ Yapılan son çalışmalara göre, BP'ler aynı zamanda osteoblastların sayı ve aktivitesini de baskılar. Hem osteoblastların hem de osteoklastların inhibisyonu, kemik rezorpsiyonun oranını azaltır. ${ }^{11-13}$ BP'ler veya diğer antirezorptif ilaçları kullanan hastalarda girişimsel dental işlemlerden (diş çekimi, dental implant yerleştirilmesi, periodontal cerrahi) sonra doku iyileşmesi sekteye uğrayarak kemik yapım yıkım işlevi bozulur ve kemik nekrozu oluşur. ${ }^{3} \mathrm{Bu}$ nedenle, çalışmamızda MRONJ modeli oluşturmak için BP uygulamasından sonra hayvanlarda diş çekimi yapıldı ve çekim soketinde kemik defekti oluşturuldu.

Paratiroid hormon (PTH), kemik metabolizmasını düzenleyen ana hormondur. Yüksek dozlarda sürekli PTH infüzyonunun iskelet sisteminde katabolik etkilere sahip olduğu bilinmektedir. Ancak, osteoporoz hastalarında aralıklı düşük doz PTH uygulamasının doğrudan yeni kemik oluşumunu teşvik ettiği ve kemiğin mekanik direncini arttırarak kırık riskini düşürdüğü kanıtlanmıştır. $^{3}$ TP tedavisinin hem osteoblastların hem de osteoklastların sayı ve aktivasyonunu stimüle ettiği, kemik yapım yıkım oranını arttırarak iskelet sistemi üzerinde osteoanabolik bir etkiye sahip olduğu bildirilmiştir. ${ }^{14}$ Üstelik TP tedavisinin BP'lerin kemik metabolizması üzerindeki antirezorptif etkisini tersine çevirebildiği gösterilmiştir. ${ }^{15}$ Literatürde MRONJ'un tedavisi için teriparatid kullanıldığını bildiren birkaç olgu sunumu bulunsa da, ilacın bu tedavi için uygulanacağı uygun dozu ve süresi tartışmalıdır. ${ }^{13}$

MRONJ'un dişlerde mobilite, ağrı, enfeksiyon veya yumuşak dokuda inflamasyon, parestezi gibi birçok klinik belirtisi bulunmasına rağmen, en karakteristik bulgusu nekroze alveol kemiğidir. ${ }^{1,16}$ Çalışmamızda, BP grubundaki hayvanların \%45'inde nekrotik alveol kemiği ve \%27'sinde iltihap akışı gözlendi. TP grubunun sadece \%9'unda nekrotik alveol kemiği görüldü ve hiçbir hayvanda iltihap akışı gözlenmedi. Ancak, TP grubundaki hayvanların sadece \%18'inde diş çekim bölgesinin tamamen iyileştiği tespit edildi. Sonuç olarak TP'nin osteonekroz geliştikten sonra klinik olarak iyileşmeye tam anlamıyla olumlu etkisinin olmadığı ama oluşan osteonekroz tablosunun daha da ilerlemesini engellediği anlaşıldı.

Kemik yapım yıkım döngüsünün biyokimyasal belirteçleri iskelet sisteminin dinamik değişimleri hakkinda bilgi verir; kemik hastalıklarının patogenez ve tedavilerini belirlemede kullanilır. Kemik rezorpsiyonunun belirlenmesinde serum CTX-1, kemik yapımının belirlenmesinde ise serum BALP değerleri biyokimyasal belirteç olarak kullanıı. BP kullanımı sonrası bu iki 
belirtecin kandaki seviyelerinin düştüğü bulunmuştur. ${ }^{1,17}$ Öte yandan, TP'nin yeni kemik oluşumu sağlayarak bu belirteçlerin kandaki seviyelerini arttırdığı gösterilmiştir. ${ }^{18}$ Neto ve ark., deneysel olarak oluşturulan BRONJ rat modelinde serumda BALP ve CTX-1 değerlerindeki değişiklikleri araştırmışlar ve BP grubundaki değerlerin istatistiksel olarak anlamlı bir şekilde azaldığını tespit etmişlerdir. ${ }^{19}$ Aksine, Kunchur ve arkadaşları MRONJ oluşumunun tahmininde CTX-1'in güvenilir olmadığı sonucuna varmışlardır. ${ }^{20} \mathrm{Bu}$ çalışmada, TP grubunun ortalama CTX-1 ve kontrol grubunun ortalama BALP değerleri diğer gruplara kıyasla daha yüksek olarak ölçülse de da gruplar arasında istatistiksel olarak anlamlı fark bulunmamıştır.

Hastalığın klinik tablosu, her zaman mukoza altındaki MRONJ lezyonunun yaygınlığını ve şiddetini tam olarak yansıtmadığından, radyolojik görüntüleme yöntemlerinin kullanımı kaçınılmaz olmaktadır. ${ }^{21}$ Radyolojik değerlendirmede konvansiyonel radyografiler, bilgisayarlı tomografi (BT), dental volumetrik tomografi (DVT), manyetik rezonans görüntüleme ve kemik sintigrafisinden faydalanılır. ${ }^{22}$ Çalışmamızda da DVT'yi kullandık. Radyolojik değerlendirmelerde MRONJ için spesifik bir bulgu olmasa da BP kullanımı sonrası radyografide osteolitik değişiklikler, kortikal ve trabeküler kemik yapısında bozulmalar görülebilir. ${ }^{23,24}$ Biasotto ve arkadaşları, BP sonrası diş çekimi yapılan deney grubundaki ratların BT görüntülerinde kortikal ve spongioz kemik defektlerine karşılık gelen bölgelerde osteolitik alanların olduğunu tespit etmişlerdir. Buna karşlık, kontrol grubundaki deneklerin radyografilerinde ise diş çekim soketinin radyolojik sınırlarında küçülme olduğunu görmüşlerdir. ${ }^{10} \mathrm{Bu}$ çalışmamızda deney hayvanlarının kemikteki iyileşme ve rezorpsiyona bağlı meydana gelen kemiksel değişiklikleri değerlendirmek için radyolojik kesitlerde görülen defektin hacmini hesapladık. BP grubunun ortalama defekt hacmi, Biasotto ve arkadaşlarının sonuçlarına benzer şekilde kontrol grubuna kıyasla istatistiksel olarak anlamlı bir şekilde daha büyük bulundu. TP grubunun ortalama defekt hacmi ise kontrol grubu hariç diğer gruplara kıyasla daha küçük olarak ölçülse de bu fark istatistiksel olarak anlamlı bulunmadı.

Osteonekrozun gösterilmesinde kullanılan önemli tanı yöntemlerinden biri de histolojik incelemedir. Düzenli olarak intravenöz BP kullanan hastalarda kemik biyopsisi almak tavsiye edilmez. Buna karşın hayvan modellerinde biyopsi yardımıyla kemiğin görülmeyen kısımları da incelenebilmektedir. Mehmet Ali Erdem ve arkaşlarının yaptıkları bir çalışmada, deney grubundaki ratlara $\mathrm{BP}$ ve deksametazon, kontrol grubundaki ratlara ise serum fizyolojik verdikten sonra diş çekimi yapılmıştır. Histolojik sonuçlara göre deney grubundaki örneklerin yeni oluşan kemik trabekül miktarı kontrol grubuna kıyasla daha düşük, nekroz bulguları ise deney grubunda daha yüksek oranda bulunmuştur. ${ }^{25}$ Çalışmamızda da benzer şekilde BP grubunda nekroza bağlı olarak kemik dokusunun tamamen iyileşmediği görülmüştür. Kontrol grubunda beklenildiği gibi, fizyolojik sert ve yumuşak doku iyileşmesi ve yeni kemik oluşumu görülmüştür. TP grubundaki kemik dokusu oluşumunun BP ve antibiyotik grubuna göre daha fazla, fakat kemik dokusu bütünlüğünün kontrol grubuna göre daha düzensiz olduğu görülmüştür. Sonuç olarak osteonekroz sonrası uygulanan antibiyotik tedavisinin iyileşmeye olumlu etkisinin olmadığı, TP'nin osteoanabolik etkisine bağlı olarak kontrol grubundan sonra en iyi yumuşak ve sert doku iyileşmesinin TP grubunda olduğu görülmüştür.

Ratlar üzerinde yapılan çalışmalarda, TP tedavisi ile osteosarkom oluşma riskinin arttığı bildirilmiştir. İlacın uzun dönem verileri olmadığı için iki yıldan uzun süreli TP tedavisi önerilmemektedir. ${ }^{21}$ Lee ve arkadaşları, TP'nin hiperkalsemik hastalıklar, osteosarkoma, metastatik kemik lezyonları, Paget hastalığı, hamilelik ve radyoterapi hikayesi bulunan hastalarda kullanılmaması gerektiğini bildirmişlerdir. ${ }^{14}$

\section{SONUÇ}

$\mathrm{Bu}$ çalışmada BP uygulamasını takiben diş çekimi işleminin osteonekroz gelişimine sebep olduğu gözlenmiştir. Osteonekroz sonrası uygulanan TP tedavisinin bu lezyonların tedavisinde kısmen olumlu etkileri olduğu görülmüştür. Bu tedavinin ideal doz ve süresinin belirlenmesi için geniş grupları içeren ileri deneysel ve klinik çalışmalara ihtiyaç vardır.

\section{Teşekkür}

Çalışmanın istatistik değerlendirmelerinde bize yardımcı olan Doç. Dr. Ferhan ELMALI ve asistanı Yasemin SEYFELI'ye teşekkür ederiz. 


\section{KAYNAKLAR}

1. Soydan S, Veziroğlu Şenel F, Araz K. Pathogenesis and Treatment of Bisphosphonate Induced Osteonecrosis of the Jaws. Clin Dent Res 2009; 33: 618.

2. Ruggiero SL, Dodson TB, Fantasia J, Goodday R, Aghaloo T, Mehrotra B, et al. American Association of Oral and Maxillofacial Surgeons position paper on medication-related osteonecrosis of the jaw-2014 update. J Oral Maxillofac Surg 2014; 72: 1938-56.

3. Dayisoylu E, Şenel F, Üngör C, Tosun E, Çankaya M, Ersöz S, et al. The effects of adjunctive parathyroid hormone injection on bisphosphonate-related osteonecrosis of the jaws: an animal study. Int $\mathrm{J}$ Oral Maxillofac Surg 2013; 42: 1475-80.

4. Kakehashi $\mathrm{H}$, Ando $\mathrm{T}$, Minamizato $\mathrm{T}$, Nakatani $\mathrm{Y}$, Kawasaki $\mathrm{T}$, Ikeda $\mathrm{H}$, et al. Administration of teriparatide improves the symptoms of advanced bisphosphonate-related osteonecrosis of the jaw: preliminary findings. Int J Oral Maxillofac Surg 2015; 44: 1558-64.

5. Shen V, Dempster D, Mellish R, Birchman WE, Horbert W, Lindsay R. Effects of combined and separate intermittent administration of low-dose human parathyroid hormone fragment (1-34) and 17ßestradiol on bone histomorphometry in ovariectomized rats with established osteopenia. Calcif Tissue Int 1992; 50: 214-20.

6. Jiang $Y$, Zhao JJ, Mitlak BH, Wang O, Genant HK, Eriksen EF. Recombinant human parathyroid hormone (1-34) [teriparatide] improves both cortical and cancellous bone structure. J Bone Miner Res 2003; 18: 1932-41.

7. Harper RP, Fung E. Resolution of bisphosphonateassociated osteonecrosis of the mandible: possible application for intermittent low-dose parathyroid hormone [rhPTH (1-34)]. J Oral Maxillofacial Surg 2007; 65: 573-80.

8. Yao M, Shimo T, Ono Y, Obata K, Yoshioka N, Sasaki A. Successful treatment of osteonecrosis-induced fractured mandible with teriparatide therapy: A case report. Int J Surg Case Rep 2016; 21: 151-53.

9. Barba-Recreo P, García-Arranz M, Yébenes L, Burgueno M. Zoledronic acid-related osteonecrosis of the jaws. Experimental model with dental extractions in rats. J Craniomaxillofac Surg 2014; 42: 744-50.

10. Biasotto M, Chiandussi S, Zacchigna S, Moimas S, Dore F, Pozatto G, et al. A novel animal model to study non-spontaneous bisphosphonates osteonecrosis of jaw. J Oral Pathol Med 2010; 39: 390-96.

11.Shimizu E, Tamasi J, Partridge NC. Alendronate affects osteoblast functions by crosstalk through EphrinB1-EphB J Dent Res 2012; 91: 268-74.
12.Pan B, To LB, Farrugia AN, Findlay DM, GreenJ, Gronthos S, et al. The nitrogen-containing bisphosphonate, zoledronic acid, increases mineralisation of human bone-derived cells in vitro. Bone 2004; 34: 112-23.

13. Keskinruzgar A, Bozdag Z, Aras MH, Demir T, Yolcu U, Cetiner S. Histopathological effects of teriparatide in medication-related osteonecrosis of the jaw: an animal study. J Oral Maxillofac Surg 2016; 74: 68-78.

14. Lee JJ, Cheng SJ, Jeng JH, Chiang CP, Lau HP, Kok SH. Successful treatment of advanced bisphosphonate-related osteonecrosis of the mandible with adjunctive teriparatide therapy. Head Neck 2011; 33: 1366-71.

15.Subramanian G, Cohen HV, Quek SY. A model for the pathogenesis of bisphosphonateassociated osteonecrosis of the jaw and teriparatide's potential role in its resolution. Oral Surg Oral Med Oral Pathol Oral Radiol Endod 2011; 112: 744-53.

16. Khan AA, Morrison A, Hanley DA, Felsenberg D, McCauley LK, O'Ryan F, et al. Diagnosis and management of osteonecrosis of the jaw: a systematic review and international consensus. J Bone Miner Res 2015; 30: 3-23.

17.Agaçayak K, Yuksel H, Atilgan S, Koparal M, Uçan MC, Özgöz $M$, et al. Experimental investigation of relationship between trauma and bisphosphonate-related osteonecrosis. Niger $\mathrm{J}$ Clin Pract 2014; 17: 559-64.

18. Keskinrüzgar A, Yanık S, Aras MH, Çetiner S. Teriparatide [parathyroid hormone (1-34)] and dentistry. Acta Odontol Turca 2015; 32: 165-70.

19. Conte Neto N, Spolidorio LC, Andrade CR, S Bastos A, Guimaraes M, Marcantonio E. Experimental development of bisphosphonaterelated osteonecrosis of the jaws in rodents. Int J Exp Pathol 2013; 94: 65-73.

20.Kunchur R, NeedA, Hughes T, Goss A. (2009). Clinical investigation of C-terminal cross-linking telopeptide test in prevention and management of bisphosphonate-associated osteonecrosis of the jaws. J Oral Maxillofac Surg 2009; 67: 116773.

21. Ersan N, Van Ruijven LJ, Bronckers AL, Olgaç V, Il üy $D$, Everts $V$. Teriparatide and the treatment of bisphosphonate-related osteonecrosis of the jaw: a rat model. Dentomaxillofac Radiol 2014; 43: 20130144.

22. Ertaş ET, AtıCl MY. Bisphosphonates and osteonecrosis of the jaws. Selcuk Dent J 2015; 2: 91-100. 
18.Bianchi SD, Scoletta M, Cassione FB, Migliaretti G, Mozatti $M$. Computerized tomographic findings in bisphosphonate-associated osteonecrosis of the jaw in patients with cancer. Oral Surg Oral Med Oral Pathol Oral Radiol Endod 2007; 104: 249-58.

19.24. Bisdas S, Pinho NC, Smolarz A, Sader R, Vogl TJ, Mack MG. Biphosphonate-induced osteonecrosis of the jaws: CT and MRI spectrum of findings in 32 patients. Clin Radiol 2008; 63: 71-7.

20.25. Ali EM, Burak CA, Cemil IS, Demircan S, Soluk M, Kasapoğlu $C$, et al. Extraction socket healing in rats treated with bisphosphonate: animal model for bisphosphonate related osteonecrosis of jaws in multiple myeloma patients. Med Oral Patol Oral Cir Bucal 2011; 16: 879-83.

Yazışma Adresi:

Dr. Cihan Topan

Erciyes Üniversitesi Diş Hekimliği Fakültesi Ağız, Diş ve Çene Cerrahisi Bölümü 38039, Melikgazi, Kayseri, Türkiye

Tel : +905556456587

Faks : +903524380657

E Posta: cihantopan@hotmail.com 